\title{
ЛЕКСИКО-СЕМАНТИЧНІ ОСОБЛИВОСТІ ФУНКЦІОНУВАННЯ ДИДАКТИЧНОЇ ЛЕКСИКИ В СПЕЦАЛЬНИХ ТЕКСТАХ
}

\author{
ОльГа ПЛАВУЦЬКА
}

\author{
кандидат педагогічних наук, \\ викладач кафедри теорії і практики перекладу \\ Тернопільського національного педагогічного \\ університету імені Володимира Гнатюка, Україна
}

\section{Наталія ПАСІЧНИК}

кандидат філологічних наук, викладач кафедри теорії і практики перекладу Тернопільського національного педагогічного університету імені Володимира Гнатюка, Україна

DOI 10.25128/2304-1222.20.51.08

\begin{abstract}
The article analyzes the combination as a way of functioning of didactic vocabulary in special texts. the views of leading linguists are analyzed, parallels between compatibility and valence are drawn as markers of the functioning of professional vocabulary in the field of education. It is noted that in the educational process the text functions as the main unit of communication and, serving the sphere of organized learning, performs its inherent functions, namely information, developmental, transformational didactic. It is indicated that the lexical structure of a scientific text, which includes certain types of didactic texts, contains commonly used words, terms and words of general scientific communication. The peculiarity of the lexical composition of the didactic text is that didactic terms have the property to move to a group of words of common language and vice versa, which indicates the incompleteness of the didactic terminology, its openness to attract new terms. It is confirmed that the two-sided functioning of the didactic text (as a source and means of pedagogical communication) testifies to its universality, and thus creates conditions for the analysis of features of lexical units in didactic texts from different angles. It is concluded that compatibility as a marker of the functioning of special texts requires further research.
\end{abstract}

Keywords: didactic vocabulary, special text, compatibility, valence.

У статті проаналізовано поєднання як спосіб функціонування дидактичної лексики у спеціальних текстах. аналізуються погляди провідних лінгвістів, проводяться паралелі між сумісністю та валентністю як маркерами функціонування професійної лексики в освітній галузі. Відзначено, що в навчальному процесі текст функціонує як основна одиниця спілкування i, обслуговуючи сферу організованого навчання, виконує властиві лише йому функції, а саме інформаційну, розвивально-виховну, трансформаційну дидактичну. Вказано, що лексичний склад наукового тексту, до якого належать окремі види дидактичних текстів, містить загальновживані слова, терміни та слова загальнонаукової комунікації. Особливістю лексичного складу дидактичного тексту є те, що дидактичні терміни мають властивість переходити до групи слів загальної мови і навпаки, що свідчить про незавершеність формування дидактичної терміносистеми, іiі відкритість до залучення нових терміноодиниць. Підтверджено, що двобічність функціонування дидактичного тексту (як джерело і засіб педагогічного спілкування) свідчить про його універсальність, а відтак створює умови для аналізу особливостей лексичних одиниць у дидактичних текстах під різним кутом зору. Зроблено висновок, що сполучуваність як маркер функціонування спеціальних текстів потребує подальшого дослідження.

Ключові слова: дидактична лексика, спеціальний текст, сумісність, валентність. 
$\mathrm{W}$ artykule przeanalizowano połączenie jako sposób funkcjonowania słownictwa dydaktycznego w tekstach specjalnych. analizowane są poglądy czołowych językoznawców, analizowowane są podobieństwa między kompatybilnością a walencją jako wyznacznikami funkcjonowania słownictwa zawodowego w dziedzinie edukacji. Należy zauważyć, że w procesie edukacyjnym tekst pełni rolę głównej jednostki komunikacyjnej i będąc sferą zorganizowanego uczenia się, spełnia jego nieodłączne funkcje, a mianowicie dydaktykę informacyjną, rozwojową, transformacyjną. Wskazuje się, że struktura leksykalna tekstu naukowego, w którego skład wchodzą określone typy tekstów dydaktycznych, zawiera powszechnie używane słowa, terminy i wyrazy komunikacji ogólnej. Osobliwością kompozycji leksykalnej tekstu dydaktycznego jest to, że terminy dydaktyczne mają właściwość przechodzenia do grupy wyrazów języka potocznego i odwrotnie, co wskazuje na niekompletność terminologii dydaktycznej, jej otwartość na przyciąganie nowych terminów. Potwierdza się, że dwustronne funkcjonowanie tekstu dydaktycznego (jako źródła i środka komunikacji pedagogicznej) świadczy o jego uniwersalności, a tym samym stwarza warunki do analizy cech jednostek leksykalnych w tekstach dydaktycznych z różnych perspektyw. Stwierdzono, że zgodność jako wyznacznik funkcjonowania tekstów specjalnych wymaga dalszych badań.

Słowa kluczowe: słownictwo dydaktyczne, tekst specjalny, kompatybilność, walencja.

Постановка проблеми. Сьогодні вивчення особливостей функціональності науковометодичної літератури є особливо актуальною проблемою в сучасному мовознавстві. Щодня 3'являються нові навчальні та методичні тексти, які водночас самі є цікавим та необхідним матеріалом для дослідження. Як відомо, сполучуваність - це поєднання за певним синтаксичним зв'язком будь-яких слів, тому як різновид дистрибуції вона охоплює не тільки валентні, а й невалентні зв' язки (узуальні й оказіональні). Якщо валентні зв'язки синтаксично оформляють як підрядні, то сполучуваність охоплює і сурядні зв'язки. Нарешті, якщо валентні зв'язки слова можна (і треба) описати вичерпно, то сполучуваність описати вичерпно неможливо “не тільки тому, що коло відповідних сполучень безмірно велике, а й тому, що воно взагалі необмежене й не замкнене суто лексично. Можна визначити загальні синтаксичні й лексичні умови, в яких ці значення реалізуються”. Лексичну сполучуваність розуміємо як контекстуальну здатність слова вступати в зв'язки з іншими словами. Залежно від факторів, які впливають на поєднання слів, розрізняють лексико-синтаксичну та лексико-фразеологічну сполучуваність. Лексико-синтаксична сполучуваність - це набір і умови реалізації синтаксичних зв'язків слова, це сполучуваність певних граматичних розрядів слів [Василько 2004].

Огляд літератури. І. Куликова зазначає, що для утворення смислу потрібно, щоб у слові відбувся процес ослаблення значення, а цей процес починається при утворенні будьякого словосполучення. У словосполученні відбувається специфікація значення, яка опирається на знання понять, реалій, і через те остання не є власне лінгвістичним процесом. При специфікації варіюється концептуальне ядро значення, відбувається зміна семного складу [Куликова 1973].

Одним із способів розкриття семантики лексичної одиниці є аналіз їі функціонування у тексті, яке відіграє важливу роль та допомагає глибше проникнути у семантичну структуру. Так, М. Кочерган вважає, що між значенням терміна і його сполучуваністю (синтагматикою) 
як формальним виявом змісту, існує двобічна залежність. Семантикою терміна зумовлюються його сполучувальні (кореляційні) потенції, а сполучуваність є транспонентом значення терміна, тому розширення чи звуження сполучуваності завжди сигналізують про зрушення у семантиці терміносистеми. Кореляція між значенням і його сполучуваністю уможливлює вивчення синонімії й антонімії, встановлення синонімічних відношень та антонімічних опозицій тощо. Опис синонімії через сполучуваність слів може здійснюватись у двох напрямах: від синонімії до сполучуваності і від сполучуваності до синонімії. У першому випадку змістовим способом встановлюються синонімічні ряди, а згодом на основі опису сполучуваності синонімів визначається оцінка ступеня синонімічності кожної пари слів $\mathrm{i}$ коректуються попередньо виокремлені чи відібрані зі словника синонімічні ряди. У другому випадку описується сполучуваність слів попередньо встановленого лексико-семантичного поля, після чого на основі близькості сполучуваності визначаються синонімічні ряди i 3'ясовується семантична відстань між ними [Кочерган 1980].

Сполучуваність антонімів 3 іншими словами, на думку М. Кочергана, нагадує сполучуваність синонімів. Це пояснюється семантичною близькістю як синонімів, так $\mathrm{i}$ антонімів. На рівні семантично-тематичних груп слова-антоніми характеризуються більшою спільністю сполучуваності, ніж синоніми. Однак якщо для синонімії важливим є виявлення спільної сполучуваності, то в антонімії основна увага зосереджена на розбіжності у сполучуваності, оскільки остання засвідчує ту сферу семантики, в якій слова антонімізуються [Кочерган 1980].

Новизна нашого дослідження полягає в тому, що вперше здійснено систематизацію англомовних методичних текстів за семантичними параметрами, де виокремлене інваріантне значення дидактичних термінів уможливлює диференціацію дидактичних текстів та текстів загальної лексики сфери освіти; пояснено процеси термінологізації загальної лексики, детермінологізації і транстермінологізації дидактичної лексики, які вживаються в англомовних методичних текстах; установлено ступінь зв'язку між семною структурою дидактичного терміна та його сполучуваністю в англомовних методичних текстах.

Мета дослідження полягає в спробі аналізу лексико-семантичних особливостей функціонування дидактичної лексики в спеціальних текстах.

Актуальність дослідження визначається сучасною тенденцією лексикографічних та дискурсознавчих студій до системного вивчення термінолексики та спеціальних фахових текстів; необхідністю їхнього комплексного дослідження для виявлення симілятивних і опозиційних зв'язків англомовної дидактичної лексики в фахових текстах, зокрема підручника та методичних розробках; потребою у комплексному аналізі семантичних та функціональних параметрів англомовних фахових текстів, а також нагальною потребою у виокремленні універсальних тенденцій щодо їхнього функціонування та застосування у навчальному процесі. 
Методологія. У дослідженні використано метод компонентного аналізу, який застосовано до словникових дефініцій дидактичної лексики для виокремлення найменших одиниць значення - сем, які є особливо ілюстративними при вивченні лексико-семантичних особливостей навчально-методичної літератури; описовий метод, що сприяє інвентаризації, сегментації, таксономії та інтерпретації англомовної дидактичної лексики; методику “значення - смисл” С. Гурського, за допомогою якої диференційовано термінологічне значення лексеми та її додаткові смисли, що виникають у спеціальних і неспеціальних текстах, до яких відносимо навчально-методичну літературу; категоріально-семантичний аналіз - для класифікації термінів і з'ясуванні їхньої приналежності до окремої категорії; валентнісний аналіз - для з'ясування особливостей функціонування англомовних дидактичних термінів, що реалізується у можливості утворення сполучень у навчально-методичній літературі, а також елементи кількісного аналізу, які дозволяють установити взаємозв'язок між якісними характеристиками дидактичного терміна та частотою його функціонування в навчальнометодичній літературі.

Результати дослідження. Як уже зазначалося вище, особливої уваги заслуговує сполучуваність англомовних дидактичних термінів. Для їх аналізу описуємо гіпонімічні відношення на базі тематично-семантичних груп, сформованих у попередніх розділах. Оскільки гіпонімія межує із синонімією, то у створенні гомонімічних пар та рядів дотримуємося принципу подібності термінологічних одиниць за їх семною структурою. Також пропонуємо ряд тематичних опозиційних пар, на основі яких прослідковуємо лексичну сполучуваність англомовного дидактичного терміна. Окрім цього, аналізуємо, яким чином семний склад дидактичного терміна впливає на його лексичну сполучуваність.

У вітчизняному та закордонному мовознавстві існує численна кількість визначень тексту. О. Селіванова трактує текст (від лат. textum - тканина, сплетіння, поєднання) як “цілісну семіотичну форму лінгвопсихоментальної діяльності мовця, концептуально та структурно інтегровану, що служить прагматичним посередником комунікації й діалогічно вбудована у семіотичний універсум культури” [Селіванова 2006].

Інший погляд висловлює Г. Кличков, зазначаючи, що текст - це “тривалий комунікативний акт, який формується відповідно до цільової установки реципієнта під час його творення та інтерпретації. Цільова установка представлена в тексті у вигляді семантичних параметрів, які задаються групою слів. При цьому виявляється, що слова, які належать до різних семантичних класів, характеризуються різноманітною текстотвірною силою” [Кличков 1986].

Така кількість визначень тексту зумовлена абсолютизацією структурної організації тексту та граматичних засобів зв'язності, формально-структурною, жанровою, стилістичною різноплановістю тексту, специфікою способу його репрезентації [там же]. 
У запропонованому дослідженні виходимо з трактування дидактичного тексту як цілісної форми лінгвопсихоментальної діяльності учасників навчального процесу, яка скерована на здійснення навчальної комунікації. Дидактичний текст застосовується для позначення мовленнєвого відрізка як в усній, так і в письмовій формі, який користувачі (ті, хто навчаються), сприймають, продукують або яким обмінюються. Мовленнєва діяльність та всі мовленнєві процеси аналізуються і класифікуються як такі, що пов'язані з відношенням користувача (учня/студента) і будь-яких співрозмовників до тексту або ж вона розглядається як закінчений продукт, художній твір, а також як мета чи продукт у процесі створення. Дидактичні тексти виконують різноманітні функції у соціальному житті і мають певні відмінності у формі та змісті, засобах, цілях і функціях, які ведуть до відповідних відмінностей не лише у контексті висловлювань, а й у їхній організації та презентації. Відповідно дидактичні тексти поділяються на різні типи, що належать до різних жанрів [Загальноєвропейські рекомендації 2003].

Будь-який текст може передаватися різними засобами, проте, як свідчать дослідники, спосіб передачі і текст тісно взаємопов'язані. Важливу роль тут відіграє тип носія та тексту, які у свою чергу залежать від виконуваної ними функції. Носіями мовлення у дидактичному дискурсі можуть бути живий голос (viva voce), телеконференція, системи публічного мовлення, радіопередачі, ТБ, кіно, комп'ютер (e-mail, CD Rom i т. д.), відеострічка, відеокасета, відеодиск, аудіострічка, -касета, -диск; друк, рукопис та інше [там же].

Лексичний склад наукового тексту, до якого належать окремі види дидактичних текстів, містить загальновживані слова, терміни та слова загальнонаукової комунікації. Особливістю лексичного складу дидактичного тексту є те, що дидактичні терміни мають властивість переходити до групи слів загальної мови і навпаки, що свідчить про незавершеність формування дидактичної терміносистеми, їі відкритість до залучення нових терміноодиниць.

Разом із зазначеними науковцями та згідно із загальноєвропейськими рекомендаціями з мовної освіти у свою чергу до усних дидактичних текстів відносимо: публічні оголошення та інструкції, публічні промови, лекції, презентації, проповіді, розваги (драма, шоу, читання. пісні), випуски новин; публічні дебати і дискусії, міжособистісні діалоги та бесіди/розмови; інтерв'ю, які можна розцінювати як і мовленнєві акти. Окремо зазначимо, що письмові дидактичні тексти містять книжки, художні й нехудожні, літературні журнали, ілюстровані журнали, газети, підручники, брошури, проспекти; листівки; словники (одномовні та двомовні), тезауруси, есе, твори, вправи, конспекти, доповіді та документи/папери, записки та повідомлення, новини (інформаційні, літературні, загальна інформація і т.д.). Щодо прагматики дидактичного тексту, то він є центром будь-якого акту дидактичного спілкування, зовнішньою предметною з'єднуваною ланкою між тим, хто продукує і тим, хто сприймає.

Дидактичні тексти відіграють важливу роль у вивченні та викладанні мов. Учні та 
студенти навчаються на основі усних і письмових текстів шляхом їхньої демонстрації та впровадженням додаткових завдань для кращого розуміння та опрацювання. Для цього створюється ряд вимог і завдань, а саме:

- представлені тексти повинні відображати життєві та лінгвістичні реалії задля кращого їх засвоєння;

- опрацювання текстів може відбуватися в усній (читання вголос друкованих текстів, усні відповіді на запитання текстів, відтворення вивчених на пам'ять текстів, парне та групове виконання вправ, участь у формальній та неформальній бесіді, вільна бесіда, презентація) та письмовій формах (диктанти, письмові вправи, твори, письмові переклади, письмові доповіді, проектні роботи, листи друзям, участь у навчальних контактах з використанням факсу та еmail).

Усні тексти є довшими, ніж презентація тієї самої інформації у письмовій формі [Ur 2007]. Узагальнимо вище викладане у наступній схемі 1.

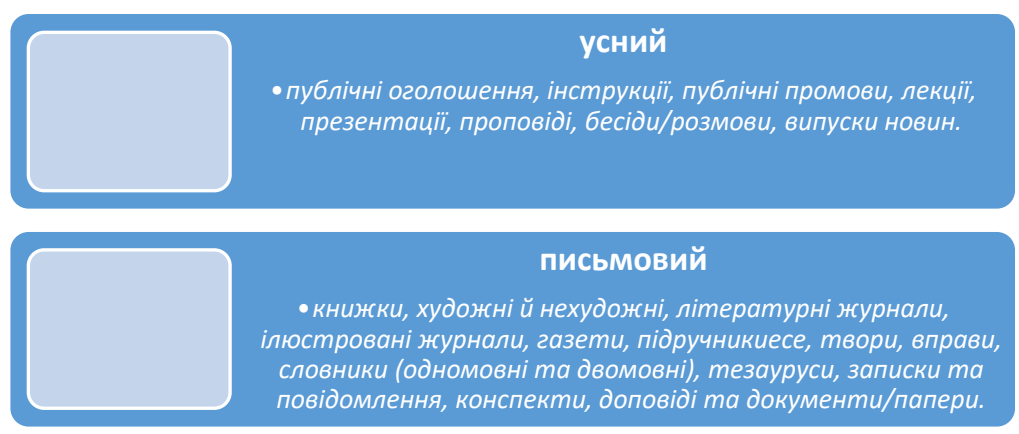

Схема 1. Дидактичні тексти

У запропонованому дослідженні схиляємося до поділу дидактичних текстів також на академічний та навчальний. На нашу думку, саме така типологія є найдоцільнішою, адже, відображаючи функції дидактичного тексту, вона націлена на його коректне використання $\mathrm{i}$ адекватний аналіз лексичних одиниць, складових академічного або навчального дидактичних текстів.

Академічний текст як різновид наукового тексту розглядаємо як певним чином організовану систему, в якій присутні всі три члени мовленнєвої ситуації: той, що передає інформацію, той, що приймає інформацію і сама інформація. Для академічного тексту основним комунікативним завданням є повідомлення самої інформації. Однак, особливої уваги заслуговують взаємовідносини обох учасників комунікації і їхнє ставлення до повідомлюваної інформації [Шубова 1970].

Важливим є питання побудови та структури академічного тексту. Академічний текст як семіотична єдність не має верхньої межі, тобто він створює світ об'єктивного пізнання і тому постає необмеженим, об'єктивним та універсальним. 3 приводу нижніх меж, або найменших одиниць тексту, то тут немає єдиної точки зору. Нижньою межею тексту можна вважати як понадфразову єдність, так і абзац або речення. Розглядаючи цю проблему з позицій 75 Studia methodologica, ISSN 2304-1222, No. 51. 2020 
інформативності, цілком закономірним є питання про розгляд дидактичного терміна як одиниці тексту, що має інформативну значущість, адекватне синтаксичне вираження $\mathrm{i}$ комунікативну цілісність. Деякі науковці схиляються до думки, що термін як найменша одиниця може породжувати науковий текст й академічний, зокрема, будь-якої протяжності аж до створення визначеної сфери об’єктивного знання [там же]. Для більшої ілюстративності пропонуємо схему структури академічного тексту (схема 2):

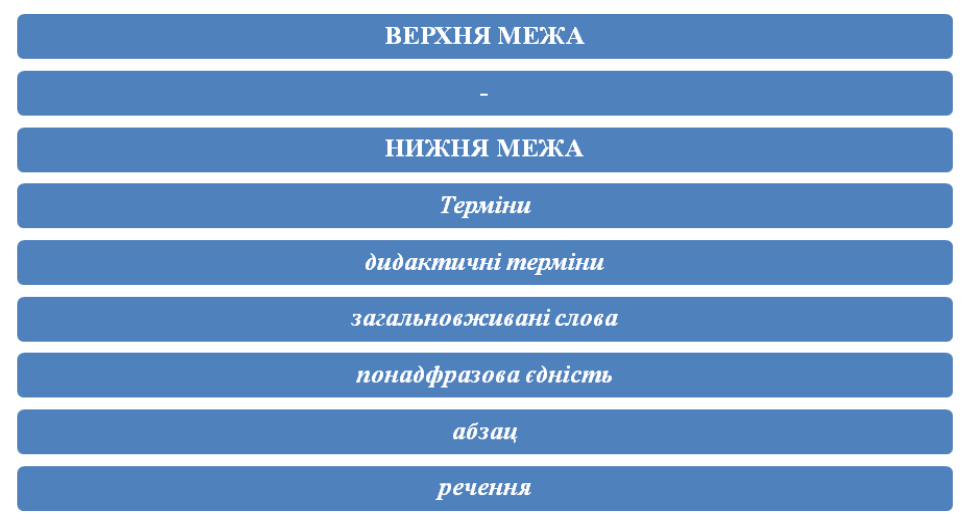

Схема 2. Структура академічного тексту

3 огляду на наявність комунікантів виникає питання про ступінь інтимізації академічного тексту. Науковому стилю, до якого належить академічний текст, притаманний низький ступінь інтимізації, зумовлений як вузькою інформаційною скерованістю, так i великою кількістю наукової, саме дидактичної термінології, оскільки будь-який науковий текст, і академічний зокрема, складається із понять, прийнятних наукою, або тих, які подаються у плані визначень, пояснень, тлумачень понять, уперше введених окремим автором [Загальноєвропейські рекомендації 2003].

До академічних відносимо тексти, які розкривають теоретичні аспекти дидактики. Вони представлені науковими статтями, монографіями, підручниками, довідниками, які стосуються проблем сфери освіти і дидактики.

Що стосується навчального тексту, тобто такого, що виступає дидактичним засобом у навчальному процесі, то він має свою сферу дослідження (схема 3).

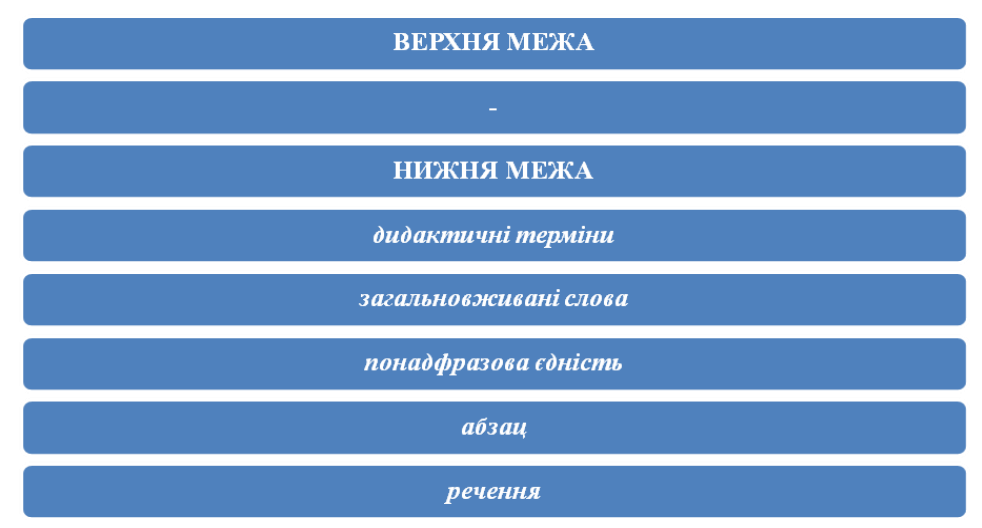

Схема 3. Навчальний текст 
Обговорення і висновки. У навчальному процесі текст функціонує як основна одиниця спілкування i, обслуговуючи сферу організованого навчання, виконує властиві лише йому функції, а саме інформаційну, розвивально-виховну, трансформаційну дидактичну. Навчальні тексти, призначені для вивчення мови, виконують два завдання: демонструють функціональні можливості мовних одиниць, які вивчаються; служать зразком і стимулом для побудови самостійного висловлювання [Самосенко 2007]. Розрізняють тексти для читання, аудіювання, говоріння, письма. Навчальні тексти розглядаються у системі комунікативного акту як зв’язна ланка між комунікантами та як продукт спілкування. При цьому враховуються усі стани процесу спілкування: комунікативні наміри мовця, соціальні ролі і відносини між комунікантами, умови здійснення комунікативного акту. Всі ці характеристики процесу спілкування відображені в текстах. Навчальний текст за обсягом, як правило, є крупною мовною одиницею, що розглядається як оптимальна одиниця навчання, продуктом якої є текст-опис, текст-розповідь, текст-роздум та їхні комбінації. Такі тексти характеризуються семантичною достатністю, цілеоформленістю та структурованістю, одночасно виступаючи частиною більшого за обсягом тексту. Варто вказати на такі переваги навчального тексту:

- текст надає можливість викладачеві i студенту виявити закономірності функціонування мови;

- розвиває лінгвістичні та аналітичні здібності студентів, їхню мовну інтуїцію і мовленнєву ініціативу;

- допомагає пізнати і зрозуміти мовну картину світу країни, мова якої вивчається [там же].

Для педагога навчальний текст є як засобом спілкування і контролю, так і одиницею навчання. Для того, хто навчається, навчальний текст служить об'єктом навчання та розуміння, джерелом нових знань, показником рівня мовної культури, виступає основою для формування і розвитку тих чи інших навиків та вмінь. Текст є базою для спостереження та осмислення лексико-граматичного матеріалу, який вивчають. Відповідно, обов'язковою вимогою до навчальних текстів $є$ насиченість лексичними одиницями та граматичними конструкціями, які є предметом вивчення на даний момент.

Вважаємо, що двобічність функціонування дидактичного тексту (як джерело і засіб педагогічного спілкування) свідчить про його універсальність, а відтак створює умови для аналізу особливостей лексичних одиниць у дидактичних текстах під різним кутом зору.

Таким чином, сполучуваність є важливим маркером функціонування дидактичної лексики в спеціальних текстах, який потребує подальшого дослідження. 


\section{ЛIТЕРАТУРА}

Ur, P. A Course in Language Teaching. Practice and Theory. Cambridge: Cambridge University Press, 2007.

Василько, 3. Значення слова і контекст. «Вісник Львівського університету. Серія Філологія». 2004. Вип. 43 (ч. 1). Львів. 244-250 [Vasil'ko Z. Znachennya slova i kontekst. "Visnik L'vivs'kogo universitetu. Seriya Filologiya". 2004. Vip. 43 (ch. 1). L'viv. 244-250].

Загальноєвропейські рекомендації з мовної освіти: вивчення, викладання, оцінювання, наук. ред. С.Ю. Ніколаєва. Київ: Ленвіт, 2003 [Zahal'noyevropeys'ki rekomendaciyi z movnoyi osviti: vivchennya, vikladannya, ocinyuvannya, nauk. red. ukraïns'kogo vidannya S. Yu. Nikolayeva. Kiyiv: Lenvit, 2003].

Кличков, Г. С., Шварц, Е. Д. Семантические признаки : роль в текстообразовании, В: Семантические признаки и их реализация в тексте. Сборник научных трудов. Волгоград: ВГПИ им. А. С. Серафимовича, 1986. 3-12 [Klichkov, G. S., Shvarts, E. D. Semanticheskie priznaki: rol'v tekstoobrazovanii. V: Semanticheskie priznaki i ih realizaciya v tekste. Sbornik nauchnyh trudov. Volgograd: VGPI im. A. S. Serafimovicha, 1986. 3-12].

Кочерган, М. П. Слово і контекст (лексична сполучуваність і значення слова). Львів: Вища школа, 1980 [Kochergan, M. P. Slovo i kontekst (leksichna spoluchuvanist' i znachennya slova). L'viv: Vishcha shkola, 1980].

Куликова, И. С. Сочетание слов как минимальный контекст лексического значення слова. Ленинград: ЛГПИ, 1973. - С. 39 [Kulikova, I. S. Sochetanie slov kak minimal'nyj kontekst leksicheskogo znachennya slova. Leningrad: LGPI, 1973].

Самосенкова, Т. В. Текст в качестве единииь обучения и профессионального речового развития иностранных студентов. «Русская филология. Украинский вестник». 2007. № 4 (34). 78-83 [Samosenkova T. V. Tekst v kachestve edinicy obucheniya i professional'nogo rechovogo razvitiya inostrannyh studentov. „Russkaya filologiya. Ukrainskij vestnik”. 2007. № 4 (34). 78-83].

Сучасна лінгвістика: термінологічна енциклопедія, (ред.) О.Селіванова. Полтава: Довкілля - Київ 2006 [Suchasna linhvistika: terminologichna enciklopediya, (ed.) O. Selivanova. Poltava: Dovkillya - Kiyiv, 2006].

Шубова, Н. А. Об исследовании лексических подсистем язика. Москва, 1970 [Shubova, N. А. Ob issledovanii leksicheskikh podsistem yazika. Moskva 1970]. 